\title{
Effect of Bioaugmentation on Biogas Yields and Kinetics in Anaerobic Digestion of Sewage Sludge
}

\author{
Magdalena Lebiocka ${ }^{1, *}$, Agnieszka Montusiewicz ${ }^{1}$ and Agnieszka Cydzik-Kwiatkowska ${ }^{2}$ \\ 1 Faculty of Environmental Engineering, Lublin University of Technology, 40B Nadbystrzycka, \\ 20-618 Lublin, Poland; a.montusiewicz@pollub.pl \\ 2 Faculty of Environmental Sciences, University of Warmia and Mazury in Olsztyn, 45g Słoneczna, \\ 10-709 Olsztyn, Poland; agnieszka.cydzik@uwm.edu.pl \\ * Correspondence: m.lebiocka@pollub.pl; Tel.: +48-81-538-4325; Fax: +48-81-538-1997
}

Received: 29 June 2018; Accepted: 8 August 2018; Published: 10 August 2018

\begin{abstract}
Bioaugmentation with a mixture of microorganisms (Bacteria and Archaea) was applied to improve the anaerobic digestion of sewage sludge. The study was performed in reactors operating at a temperature of $35^{\circ} \mathrm{C}$ in semi-flow mode. Three runs with different doses of bioaugmenting mixture were conducted. Bioaugmentation of sewage sludge improved fermentation and allowed satisfactory biogas/methane yields and a biodegradation efficiency of more than $46 \%$, despite the decrease in hydraulic retention time (HRT) from $20 \mathrm{~d}$ to $16.7 \mathrm{~d}$. Moreover, in terms of biogas production, the rate constant $\mathrm{k}$ increased from $0.071 \mathrm{~h}^{-1}$ to $0.087 \mathrm{~h}^{-1}$ as doses of the bioaugmenting mixture were increased, as compared to values of $0.066 \mathrm{~h}^{-1}$ and $0.069 \mathrm{~h}^{-1}$ obtained with sewage sludge alone. Next-generation sequencing revealed that Cytophaga sp. predominated among Bacteria in digesters and that the hydrogenotrophic methanogen Methanoculleus sp. was the most abundant genus among Archaea.
\end{abstract}

Keywords: anaerobic digestion; wastewater sludge; bioaugmentation; metagenome; NGS

\section{Introduction}

The development of wastewater treatment technology, together with the implementation of environmental legislation, has successfully protected the aquatic environment from pollution. However, at the same time, sewage sludge is generated as the by-product of the wastewater treatment. Sewage sludge is becoming a worldwide environmental problem because of its increasing production and its high contents of organic matter, pathogens, and heavy metals.

Anaerobic digestion is a biological process that can degrade organic material by the concerted action of a wide range of microorganisms in the absence of oxygen. However, the advantages of the anaerobic digestion process in the treatment of sewage are still far from being optimized. Regardless of the temperature conditions, only around $50 \%$ to $60 \%$ of the organic matter can be degraded, leaving a large potential of increasing the biogas production [1]. A better understanding of the basic mechanisms occurring in the digester, conducting the process at high temperatures, application of different kinds of pre-treatment methods (freezing/thawing; cavitation), phase separation, and, recently, bioaugmentation has been applied to improve the anaerobic digestion.

Bioaugmentation is the addition (augmentation) of specialized microbial cultures which are typically grown separately under well-defined conditions to perform a specific task in a given environment (in situ or in a bioreactor) [2,3]. This approach has been used for hazardous waste remediation, as well as for the biodegradation of wastewater in wastewater treatment plants and many others biological treatment processes [4]. In aerobic wastewater treatment, bioaugmentation has resulted in more reliable nitrification, biological phosphorous removal, improved sludge settling, 
enhanced grease degradation, and accelerated transformation of xenobiotic organic contaminants, such as pentachlorophenol [5-8]. Bioaugmentation has also been studied at laboratory scale to increase the methane production during the anaerobic digestion of animal manure [9], cellulose-rich [10,11], and lipid-rich waste [12] as well as seed biomass [13]. Schmidt et al. [14] used bioaugmentation during the anaerobic digestion of sewage sludge to improve the polycyclic aromatic hydrocarbons removal. Moreover, the bioaugmentation of anaerobic digestion communities by the adapted hydrolytic consortia increased the biogas yield by $10-29 \%$ in the anaerobic digestion of maize silage [15].

Interestingly, bioaugmentation was investigated as a method of decreasing the recovery period of anaerobic digesters exposed to a transient toxic event $[16,17]$. The comprehensive review by Tale et al. [18] described the beneficial effects of bioaugmentation on the efficiency of biochemical processes under temporary organic overloading of reactors. Bioaugmentation has been considered as a useful strategy, playing an excellent role for performance enhancement and recovery in biosystems under various stresses due to the improvement of detrimental conditions, retention, and adaptation of bioaugmentation consortium. However, bioaugmentation faces the potential risk of functional failure, even negative effects on biosystems [19]. Failure of bioaugmentation has been reported to be associated with numerous factors that include the growth rate being lower than the rate of washout, insufficient inoculum size, and substrate availability. Limitations of bioaugmentation can be overcome through the techniques that include increased inoculum dosing, a longer period of inoculum acclimatization in reactors, the addition of nutrients and surfactants, and application of sufficient acclimatization periods. Surveys of the literature show that a key area for the further research should be towards acquiring a better understanding of the degradation pathways where bioaugmentation is applied [20-22]. The present study examines the influence of bioaugmentation on the efficiency of anaerobic digestion of sewage sludge from a municipal wastewater treatment plant. The novel aspect of the study involved using a mixture of wild-living Bacteria and Archaea from Yellowstone National Park, USA, for bioaugmentation. The effect of this bioaugmentative mixture on the kinetics of biogas production and the microbial structure in semi-flow anaerobic reactors was determined.

\section{Materials and Methods}

\subsection{Material Characteristics}

Sewage sludge that included two-source residues (originated from primary and secondary clarifiers) were obtained from the Puławy municipal wastewater treatment plant (WWTP), Poland. Sludge was sampled once a week in the WWTP. Under laboratory conditions, the sludge was mixed at the volume ratio of 60:40 (primary: waste sludge), then homogenized, manually screened through a $3 \mathrm{~mm}$ screen and partitioned. The sludge samples were stored at $4{ }^{\circ} \mathrm{C}$ in a laboratory fridge for no longer than one week. Sludge prepared in this manner was fed to the digester as mixed sewage sludge (SS). The main characteristics of SS during the entire cycle of experiments was as follows (the average value and standard deviation are given): chemical oxygen demand (COD) $-43.00 \pm 5.49 \mathrm{~g} \mathrm{dm}^{-3}$, volatile fatty acids (VFA) $-1179 \pm 733 \mathrm{mg} \mathrm{dm}^{-3}$, total solids (TS) $-37.0 \pm 2.9 \mathrm{~g} \mathrm{~kg}^{-1}$, volatile solids (VS)—28.6 $\pm 2.11 \mathrm{~g} \mathrm{~kg}^{-1}, \mathrm{pH}-6.75 \pm 0.33$, and alkalinity-846 $\pm 268 \mathrm{mg} \mathrm{CaCO}_{3} \mathrm{dm}^{-3}$.

A liquid solution containing a mixture of Bacteria and Archaea was prepared in a continuous mode throughout the experiment. A nylon pouch filled with a powdery substrate (ArcheaSolutions Inc., Evansville, IN, USA) was placed inside a generator. The microbial composition of the powdery substrate after 1 day of cultivation at $37^{\circ} \mathrm{C}$ under constant mixing conditions in distilled water showed that about $36 \%$ of microorganisms belonged to Archaea with Methanosaeta as s predominant genus and that about $59 \%$ of microorganisms belonged to Bacteria with Exiguobacterium, Janthinobacterium, Acinetobacter, and Stenotrophomonas as the most abundant genera (Figure 1). 


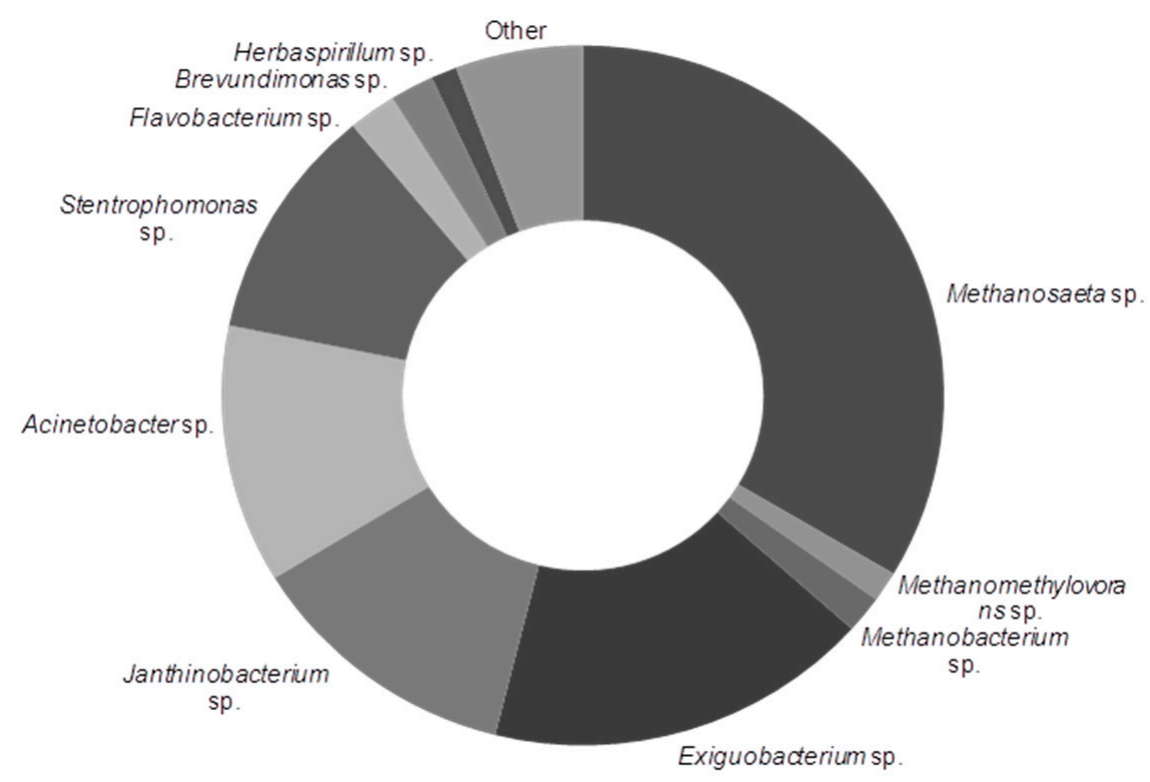

Figure 1. Microbial genera present in the bioaugmenting substrate; "other" includes unclassified bacteria (1\%) and Archaea (1\%), and taxa with abundance below $1 \%(3 \%)$; sequencing results are present in the Sequence Read Archive SRA (National Center for Biotechnology Information NCBI, BioProject PRJNA431048).

The analysis of the substrate was performed as described in Molecular analysis, sequences were placed in NCBI (BioProject PRJNA431048). The substrate was packed in a vinyl alcohol coating, which dissolved upon contact with dechlorinated pipe water flowing through the device. The release of an appropriate microbial content of $1.08 \mathrm{~g} \mathrm{~L}^{-1} \mathrm{~h}^{-1}$ required a continuous flow of water at a level of about $0.5 \mathrm{~L} \mathrm{~min}^{-1}$. After 30 days, the pouch containing a mixture of microorganisms was replaced by a new one. The generator was linked to two serially-connected storage tanks with a total active volume of $320 \mathrm{~L}$. The liquor prepared in this manner was stored at room temperature. The average total solids (TS) of the liquor differed slightly during the experiments and reached 0.48 and $0.45 \mathrm{~g} \mathrm{~kg}^{-1}$ in phase 1 and phase 2, respectively, while the average volatile solids (VS) oscillated around $0.04 \mathrm{~g} \mathrm{~kg}^{-1}$. The COD values were $22 \mathrm{~g} \cdot \mathrm{m}^{-3}$ in phase 1 and $26 \mathrm{~g} \cdot \mathrm{m}^{-3}$ in phase 2 . Similarly, the VFA concentrations were 21 and $24 \mathrm{~g} \cdot \mathrm{m}^{-3}$, respectively. The alkalinity of $330 \mathrm{~g} \mathrm{CaCO} \cdot \mathrm{m}^{-3}$ and $\mathrm{pH}$ value of 7.16 were obtained for both phases.

\subsection{Laboratory Installation and Operational Set-Up}

The study was performed in anaerobic reactors operating at a temperature of $35^{\circ} \mathrm{C}$ in semi-flow mode. The laboratory installation consisted of three completely mixed digesters (with an active volume of $40 \mathrm{dm}^{3}$ ) working in parallel, equipped with a gaseous installation (consisting of pipelines, pressure equalization unit and a mass flow meter), an influent peristaltic pump and storage vessels (Figure 2).

An inoculum for the laboratory reactors was taken from Puławy wastewater treatment plant as a collected digest from a mesophilic anaerobic digester with a volume of $2500 \mathrm{~m}^{3}$ that was operated at $35-37^{\circ} \mathrm{C}$ and a hydraulic retention time (HRT) of about 25 days. The adaptation of the digester biomass was achieved after 30 days.

Two phases of the experiment were conducted, differing in the organic loading rates (OLRs). Each phase lasted 90 days (30 days for acclimatization and 60 days for measurements). In the first phase, three reactors were operated. The first reactor (R1—control one) was fed daily with $2 \mathrm{dm}^{3}$ of mixed sludge. The HRT reached 20 days, and the OLR was time-dependent with an average value of $1.55 \mathrm{~kg} \mathrm{VS} \mathrm{m}^{-3}$ day $^{-1}$. 


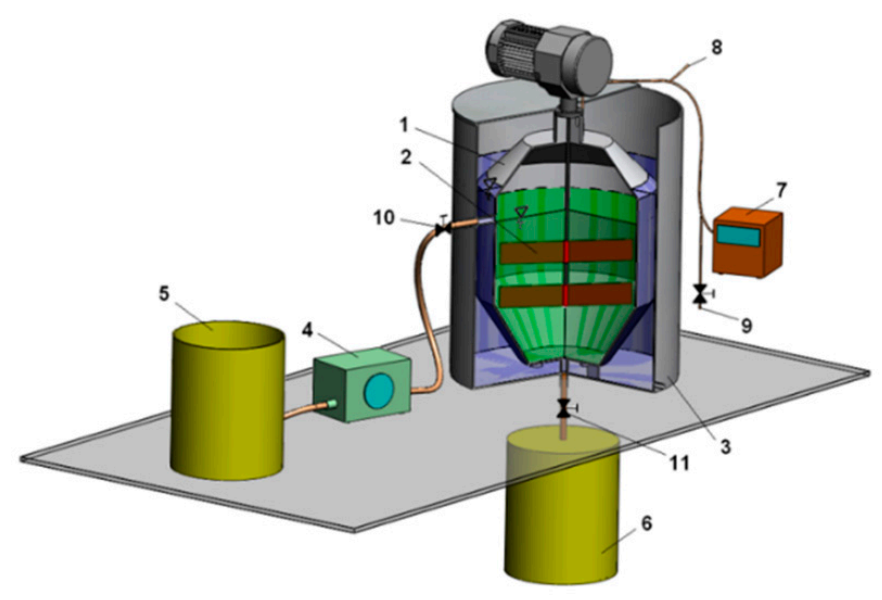

Figure 2. Laboratory installation. 1-anaerobic reactor, 2-mechanical stirrer, 3-heating jacket, 4-influent peristaltic pump, 5-influent storage vessel, 6-effluent storage vessel, 7-drum gas meter, 8-gaseous installation and gas sampler with a rubber septum, 9-dewatering valve, 10-inlet valve, 11-outlet valve.

The second reactor (R2) was operated following the same schedule. However, the reactor was fed with sludge bioaugmented with microbial mixture at a volumetric ratio of 91:9 (the influent consisted of a mixture of $2 \mathrm{dm}^{3}$ sludge and $0.2 \mathrm{dm}^{3}$ of bioaugmenting mixture). The HRT was shortened to 18.2 days, and the average value of the OLR was $1.54 \mathrm{~kg} \mathrm{VS} \mathrm{m}^{-3}$ day $^{-1}$.

The third reactor (R3) arrangement was the same as in R2, but this time the volumetric ratio was set at 87:13 (influent consisted of a mixture of $2 \mathrm{dm}^{3}$ sludge and $0.3 \mathrm{dm}^{3}$ of bioaugmenting mixture). The HRT shortened to 17.4 days, and the average value of the OLR was $1.53 \mathrm{~kg} \mathrm{VS} \mathrm{m}^{-3} \mathrm{day}^{-1}$.

In the second phase, two reactors were operated. The fourth reactor (R4) was operated analogously to the R1 (as a control), although at OLR of only $1.30 \mathrm{~kg} \mathrm{VS} \mathrm{m}^{-3}$ day $^{-1}$.

Reactor R5 was operated also at low OLR of $1.33 \mathrm{~kg} \mathrm{VS} \mathrm{m}^{-3}$ day, and the sludge to bioaugmenting mixture volumetric ratio was set at 83:17 (influent consisted of a mixture of $2 \mathrm{dm}^{3}$ sludge and $0.4 \mathrm{dm}^{3}$ of bioaugmenting mixture). The HRT was shortened to 16.7 days.

The reactors were bioaugmented in continuous mode because of the long-term wide microbial growth (from $20 \mathrm{~h}$ to 20 days) as well as their possible wash out from the system.

\subsection{Analytical Methods}

In the mixed sludge (SS), total chemical oxygen demand (COD), total solids (TS) and volatile solids (VS), were analyzed once a week. The same schedule was used for determining the values of the parameters that characterized the supernatant (sludge liquid phase) before digestion. These parameters included soluble chemical oxygen demand (SCOD), volatile fatty acids (VFA), alkalinity and $\mathrm{pH}$ level. The supernatant samples were obtained by centrifuging the sludge at $4000 \mathrm{rpm}$ for $30 \mathrm{~min}$. All analyses were carried out in accordance with the procedures listed in the Standard Methods for the Examination of Water and Wastewater [23].

The bioaugmenting mixture was examined twice a week as an averaged and a collected sample taken from its storage tank. The following parameters were analyzed: COD, TS, VS, VFA, alkalinity, and $\mathrm{pH}$.

In the digested sludge, the specified parameters were determined two times a week, in accordance with the timetable adopted. Similarly, the supernatant of the digested sludge was examined using the same schedule.

Anaerobic digestion efficiency was controlled by the daily evaluation of the biogas yield and its composition $\left(\mathrm{CH}_{4}, \mathrm{CO}_{2}\right.$, and other gases). Moreover, the volatile solids removal efficiency was evaluated according to the American Public Health Association (APHA) [23]. 
The biogas production was determined using Aalborg (USA) digital mass flow meter. Its composition was measured using Trace GC-Ultra gas chromatograph coupled with a thermal conductivity detector (TCD) fitted with divinylbenzene (DVB) packed columns. The Rt-Q-Bond column was used to determine the $\mathrm{CH}_{4}$ and $\mathrm{CO}_{2}$ concentrations. The parameters used for the analysis were as follows-injector $50{ }^{\circ} \mathrm{C}$ and detector $100{ }^{\circ} \mathrm{C}$. The carrier gas was helium with a flux rate of $1.5 \mathrm{~cm}^{3} \cdot \mathrm{min}^{-1}$. Peak areas were determined by the computer integration program (CHROM-CARD).

The biogas production curves were made on the basis of the averaged experimental data acquired from an XFM Control Terminal. Both the rate constant $k$ and maximum biogas production $V_{\max }$ were obtained by means of nonlinear regression method with Statsoft Statistica software (version 10, TIBCO Software Inc., Palo Alto, CA, USA). The strength of the relationships between groups of the results was determined using Pearson's correlation coefficient $(R)$ and determination coefficient $R^{2}$.

\subsection{Molecular Analysis}

Metagenome of the digesters in the first phase was analyzed after 90 days of each reactor operation. The collected samples of biomass were stored at $-20^{\circ} \mathrm{C}$. After thawing, DNA was isolated from the biomass using GenElute ${ }^{\mathrm{TM}}$ Bacterial Genomic DNA Kit (Sigma-Aldrich Chemie Gmbh, Munich, Germany) according to the producer's protocol, including lysozyme digestion. The presence of DNA was confirmed by agarose electrophoresis. Purity and concentration of the isolated DNA were measured spectrophotometrically using a Biophotometer (Eppendorf, Hamburg, Germany). A universal 515F (GTGCCAGCMGCCGCGGTAA) and 806R (GGACTACHVGGGTWTCTAAT) primer set was used to amplify the archaeal and bacterial 16S rDNA gene. Next-generation sequencing (NGS) using the MiSeq Illumina platform was applied to sequence the amplicons. The sequencing was performed in the Research and Testing Laboratory (USA). Over 126 thousands of full sequences were obtained.

The sequences were analyzed bioinformatically as described in Świątczak et al. [24]. In short, to detect and remove chimeras from the raw reads, UCHIME [25] was applied. The readouts were condensed into FASTA format and clustered into operational taxonomic units (OTUs) using USEARCH global alignment [26]. A .NET algorithm utilizing BLASTN+ was used to query FASTA formatted file with seed sequences for each cluster against a database of NCBI derived sequences. Sequences were aligned by Infernal [27] and clustered by Complete Linkage Clustering (a module of the RDPipeline, https://rdp.cme.msu.edu/). The Shannon-Wiener index of diversity $\left(\mathrm{H}^{\prime}\right)$ [28] was calculated (at a level of species). Samples were from the same run and have a similar number of reads; therefore, normalization was not performed to avoid data loss. Rarefaction analysis was performed using a module of the RDPipeline. The sequences have been deposited in the Sequence Read Archive (SRA) NCBI within BioProjectPRJNA380917 as an experiment 'Metagenome of bioaugmented anaerobic digesters.'

\section{Results and Discussion}

\subsection{Impact of Bioaugmentation on the Efficiency of Anaerobic Digestion of Sewage Sludge}

The characteristics of both the mixtures feeding the reactors and the digests are presented in Figure 3. As indicated in the figure, the characteristics of SS varied in the control reactors (R1 and R4), which probably resulted from the changes in the chemical composition of sewage (Figure 1, Table 1).

Bioaugmentation by a mixture of Bacteria and Archaea decreased all parameters in the feedstock (due to dilution) as compared to sewage sludge. Decreases in COD concentration from $45.8 \mathrm{~g} \mathrm{dm}^{-3}$ to $39.8 \mathrm{~g} \mathrm{dm}^{-3}$ and $38.6 \mathrm{~g} \mathrm{dm}^{-3}$, VS from $31.0 \mathrm{~g} \mathrm{~kg}^{-1}$ to 28.1 and $26.4 \mathrm{~g} \mathrm{~kg}^{-1}$, and TS from $40.1 \mathrm{~g} \mathrm{~kg}^{-1}$ to $36.4 \mathrm{~g} \mathrm{~kg}^{-1}$ and $34.2 \mathrm{~g} \mathrm{~kg}^{-1}$ were observed for R1, R2, and R3, respectively. The concentration of SCOD in the bioaugmented reactors was 1.25 and $1.20 \mathrm{~g} \mathrm{dm}^{-3}$ and was lower than that in the control $\left(1.40 \mathrm{~g} \mathrm{dm}^{-3}\right.$ ). Similarly, in R4 and R5, the concentration of VS and TS decreased by $15 \%$ (from 26.1 to $22.1 \mathrm{~g} \mathrm{~kg}^{-1}$ and from 33.9 to $28.8 \mathrm{~g} \mathrm{~kg}^{-1}$, respectively), COD by $13.5 \%$ (from 38.3 to $33.1 \mathrm{~g} \mathrm{dm}^{-3}$ ), 
and SCOD by $9 \%$ (from 2.5 to $2.3 \mathrm{~g} \mathrm{dm}^{-3}$ ). The higher the dose of the bioaugmenting mixture, the greater the decrease in the aforementioned characteristics as compared to the control reactors.
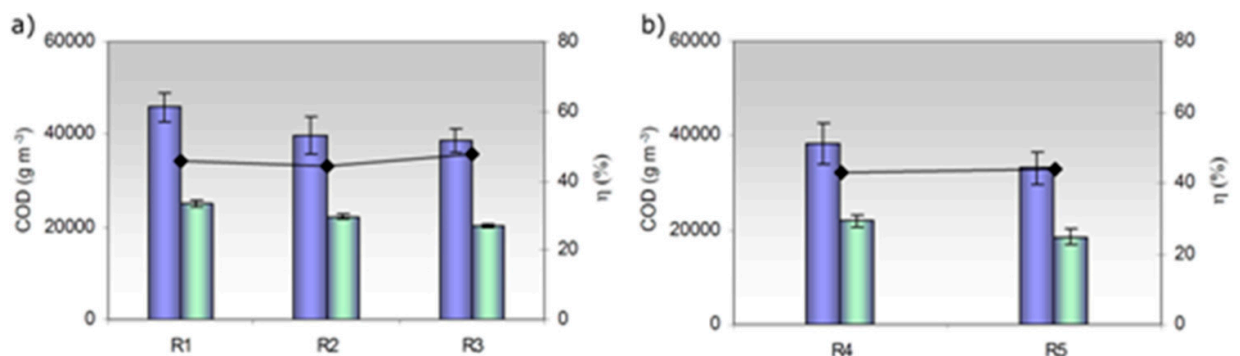

c)
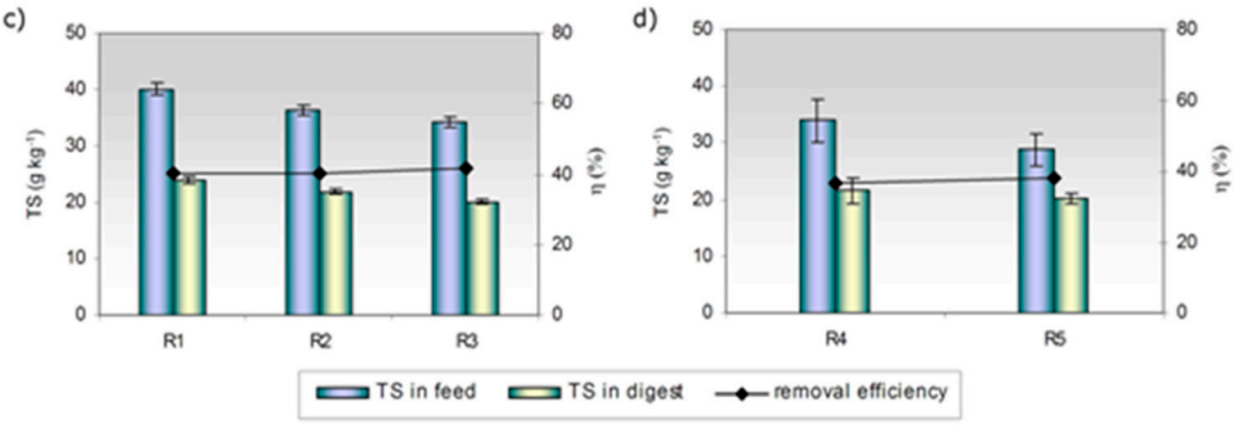

e)
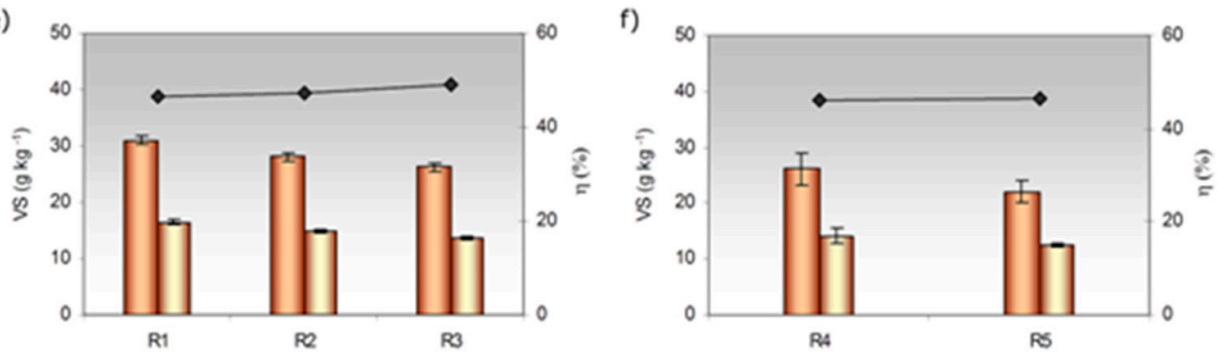

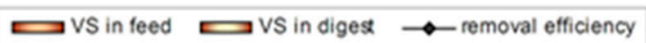

9)
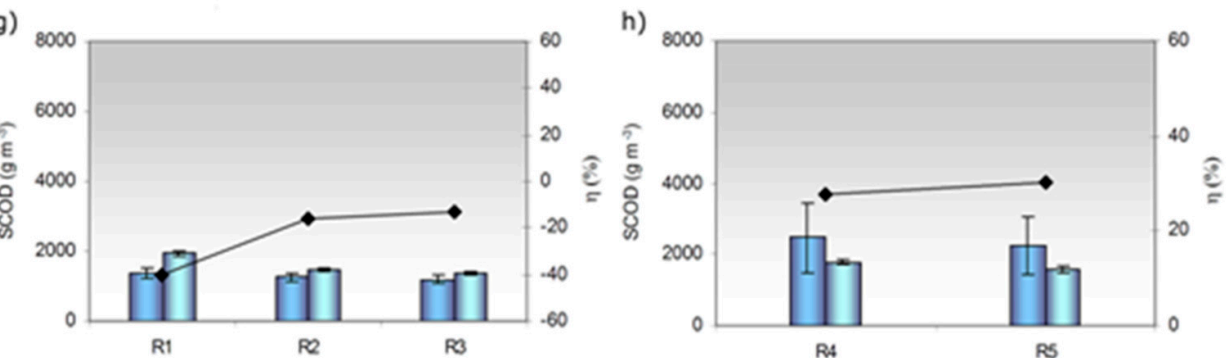

$\Longrightarrow \mathrm{SCOD}$ in feed $\rightleftharpoons \mathrm{SCOD}$ in diges

Figure 3. Concentration of organic compounds (expressed as chemical oxygen demand (COD), total solids (TS), volatile solids (VS), and soluble chemical oxygen demand (SCOD)) in feed and digest, as well as related removal efficiencies (average values are given, error bars represent $95 \%$ confidence limits for means): (a) COD changes in phase 1, (b) COD changes in phase 2, (c) TS changes in phase 1, (d) TS changes in phase 2, (e) VS changes in phase 1, (f) VS changes in phase 2, (g) SCOD changes in phase 1 , (h) SCOD changes in phase 2.

The degrees of removal pertaining to VS and other parameters were used to evaluate the process efficiency. On average, the removal efficiencies of VS in R2, R3, and R5 (the bioaugmented reactors) amounted to $47.3 \%, 49.2 \%$, and $46.4 \%$, respectively. These values were greater than the ones obtained 
for sewage sludge (Figure 3); however, the difference was not statistically significant. The highest removal of VS was observed in the presence of $13 \% v / v$ dose of the bioaugmenting mixture (R3), despite the shortening of HRT from 20 to $17.4 \mathrm{~d}$. On the other hand, the removal efficiency of TS reached $40.5 \%, 41.7 \%$, and $37.9 \%$ in R2, R3, and R5, respectively; for the control reactors, it was slightly lower, equaling $40.0 \%$ and $35.6 \%$ for R1 and R4 control reactors, respectively. As far as the removal efficiency of COD is concerned, comparable values were observed for all reactors. However, the maximum COD removal efficiency, reaching $47.6 \%$, was obtained with $13 \% v / v$ dose of the bioaugmenting mixture (R3). This observation is in line with the findings of Yu et al. [29], who reported that the application of bioaugmentation during the mature landfill leachate treatment slightly improved the COD removal efficiency. Interestingly, visible differences were observed for the efficiency of SCOD removal (Figure 3g,h). In comparison with the non-bioaugmented reactors, the SCOD removal efficiency increased by $24 \%$ and $27 \%$, in the reactors (R2, R3, R5) supplemented with $9 \%$ and $13 \%$ of bioaugmenting mixture. In contrast, in the presence of $17 \% v / v$ of bioaugmenting mixture, the increase was only by $2.5 \%$. To sum up, the removal efficiency of organic compounds increased, although the hydraulic retention time was shortened from 20 to $16.7 \mathrm{~d}$. Hailei et al. [30] also reported that the addition of mixed microorganisms could shorten the sludge acclimation time, as well as improve the treatment efficiency.

\subsection{Process Stability}

To evaluate the stability of anaerobic digestion, $\mathrm{pH}$, alkalinity, concentration of VFA and the VFA/alkalinity ratio in digest supernatant should be analyzed. The average values of these parameters in the feedstock and digest are given in Table 1.

Table 1. Volatile fatty acids (VFA) concentration, alkalinity and $\mathrm{pH}$ values in feed and digest for specified reactors.

\begin{tabular}{cccccccc}
\hline \multirow{2}{*}{ Reactor } & \multirow{2}{*}{ Value } & \multicolumn{2}{c}{ VFA $\left(\mathrm{g} \mathrm{m}^{-3}\right)$} & Alkalinity $\left(\mathrm{g} \mathrm{CaCO}_{3} \mathbf{~ m}^{-3}\right)$ & \multicolumn{2}{c}{$\mathbf{p H}$} \\
\cline { 3 - 7 } & & Feed & Digest & Feed & Digest & Feed & Digest \\
\hline \multirow{2}{*}{ R1 } & Average & 838 & 235 & 812 & 3722 & 6.81 & 7.99 \\
& lower/upper 95\% mean & $719 / 957$ & $66 / 404$ & $764 / 860$ & $3614 / 3830$ & $6.68 / 6.94$ & $7.95 / 8.03$ \\
\hline \multirow{2}{*}{ R2 } & Average & 771 & 241 & 769 & 3391 & 6.83 & 7.86 \\
& lower/upper 95\% mean & $678 / 864$ & $112 / 370$ & $732 / 806$ & $3268 / 3514$ & $6.70 / 6.96$ & $7.80 / 7.92$ \\
\hline \multirow{2}{*}{ R3 } & Average & 660 & 291 & 749 & 3336 & 6.82 & 7.72 \\
& lower/upper 95\% mean & $542 / 778$ & $203 / 379$ & $712 / 786$ & $3229 / 3443$ & $6.68 / 6.96$ & $7.66 / 7.78$ \\
\hline \multirow{2}{*}{ R4 } & Average & 1520 & 149 & 880 & 3670 & 6.68 & 7.71 \\
& lower/upper 95\% mean & $147 / 2893$ & $115 / 183$ & $610 / 1150$ & $3524 / 3816$ & $6.44 / 6.92$ & $7.44 / 7.98$ \\
\hline \multirow{2}{*}{ R5 } & Average & 1062 & 253 & 754 & 3195 & 6.75 & 7.59 \\
& lower/upper 95\% mean & $163 / 1961$ & $167 / 339$ & $578 / 930$ & $3078 / 3312$ & $6.53 / 6.97$ & $7.37 / 7.81$ \\
\hline
\end{tabular}

The results indicate that the $\mathrm{pH}$ of feedstock was at a comparable level in the bioaugmented and non-bioaugmented reactors. Conversely, alkalinity decreased in the bioaugmented reactors (R2, R3, and R5) by $5.5 \%, 8.4 \%$, and $16.7 \%$, respectively, but the differences were not statistically significant. An increase in $\mathrm{pH}$ was observed in the digest. The values for all runs were in a range favorable for methanogens, i.e., from $\mathrm{pH} 7.59$ to $\mathrm{pH}$ 7.99. Similarly, the digest alkalinity increased more than 4 -fold. In the bioaugmented reactors, $\mathrm{pH}$ and alkalinity were lower compared with the sewage sludge, and these differences were statistically significant. Bioaugmentation caused a decrease in the VFA of the mixture fed to the reactor, but the difference was not statistically significant. Higher VFA removal was reported for anaerobic digestion of sewage sludge: $71.9 \%$-in R1, and $90.2 \%$-in R4. For bioaugmented reactors, these values were $68.8 \%(\mathrm{R} 2), 55.6 \%$ (R3), and $76.2 \%$ (R5). The digest was characterized by low concentrations of VFA-they did not exceed the value of $290 \mathrm{~g} \mathrm{~m}^{-3}$ in any reactor. In the presence of the bioaugmenting mixture, the VFA/alkalinity ratio increased to 0.071 and 0.087 (for $9 \%$ and 13 
$v / v$ dose, respectively) and $0.079(17 \% v / v)$. For the sludge, the ratio equaled 0.063 in R1 and 0.041 in R4. The process was carried out under stable conditions in both phases.

\subsection{Biogas Production}

The results of the investigations are shown in Table 2 (average data are reported). It should be noted that the feed conditions varied through phases (R1-R3 and R4-R5), which was attributed both to the changes in sludge characteristics and the addition of microorganisms from the bioaugmenting mixture. In terms of organic matter removed via anaerobic digestion, regardless of the feedstock, the lowest biogas yield was observed for the removed COD, while the highest for the removed VS. Considering organic substances fed to the reactor, a higher biogas yield was noted in terms of VS and lower regarding TS (Table 2).

The addition of microorganisms from the bioaugmenting mixture had no significant influence on the biogas production (the differences of means were not statistically significant). However, the biogas yields, as well as daily biogas production, were enhanced compared to the control (particularly for $\mathrm{R} 2$ and R3). These occurred despite the progressive decrease in the hydraulic retention time (HRT) from $20 \mathrm{~d}$ to $16.7 \mathrm{~d}$ that led to the faster washing out of the microorganisms from the semi-flow system. Moreover, similar methane content was noted independently of the mixture dose. It was also shown that bioaugmentation enabled to obtain higher biodegradation efficiency regarding the VS removal within shorter HRT. The above suggests the beneficial bioaugmentation effect. The results achieved could be attributed to the increase in rates of both biogas production and organics decomposition. It was due to the differences between the microbial communities of the bioaugmented digesters and the enhanced activity of microorganisms involved in bioaugumentation of anaerobic digestion. This explanation is consistent with the research by Duran et al. [31] regarding bioaugmentation with selected strains belonging to Baccillus sp., Pseudomonas sp., and Actinomycetes sp. The slight increase in biogas yields throughout bioaugmentation could result both from the HRT shortening and the TS/VS feedstock dilution by bioaugmenting mixture. The second one followed by the procedure of mixture preparation recommended by ArcheaSolutions Inc. To significantly improve the biogas yields, the higher concentration of the bioaugmenting mixture would be profitable. This could be achieved in the future research using a microfiltration module. The study of Poszytek et al. [32] using a novel bacterial strain Ochrobactrum sp. POC9 for bioaugmentation of sewage sludge anaerobic digestion revealed much better results than the ones presented here. In that case, the cumulative biogas production increased by $22.06 \%$ compared to the control, although the study was conducted in batch mode.

Table 2. Biogas production and corresponding yields as well as methane content for bioaugmented and non-bioaugmented reactors.

\begin{tabular}{|c|c|c|c|c|c|c|}
\hline Parameter & Unit & R1 (Control) & $\mathbf{R} 2$ & R3 & R4 (Control) & R5 \\
\hline $\begin{array}{l}\text { Daily biogas } \\
\text { production }^{\text {a }}\end{array}$ & $\mathrm{dm}^{3} \mathrm{~d}^{-1}$ & $23.23 \pm 3.7^{b}$ & $24.26 \pm 3.8$ & $24.53 \pm 3.8$ & $19.59 \pm 2.2$ & $19.86 \pm 2.1$ \\
\hline \multirow[t]{5}{*}{ Biogas yield } & $\mathrm{m}^{3} \mathrm{~kg}^{-1} \mathrm{VS}$ added & $0.38 \pm 0.07$ & $0.40 \pm 0.07$ & $0.40 \pm 0.07$ & $0.38 \pm 0.05$ & $0.37 \pm 0.05$ \\
\hline & $\mathrm{m}^{3} \mathrm{~kg}^{-1} \mathrm{TS}$ added & $0.29 \pm 0.05$ & $0.31 \pm 0.05$ & $0.31 \pm 0.05$ & $0.29 \pm 0.04$ & $0.29 \pm 0.04$ \\
\hline & $\mathrm{m}^{3} \mathrm{~kg}^{-1} \mathrm{VS}$ removed & $0.83 \pm 0.20$ & $0.86 \pm 0.21$ & $0.84 \pm 0.21$ & $0.82 \pm 0.22$ & $0.83 \pm 0.22$ \\
\hline & $\mathrm{m}^{3} \mathrm{~kg}^{-1} \mathrm{TS}$ removed & $0.75 \pm 0.18$ & $0.78 \pm 0.21$ & $0.77 \pm 0.19$ & $0.79 \pm 0.27$ & $0.78 \pm 0.29$ \\
\hline & $\mathrm{m}^{3} \mathrm{~kg}^{-1}$ COD removed & $0.52 \pm 0.09$ & $0.53 \pm 0.11$ & $0.53 \pm 0.11$ & $0.55 \pm 0.09$ & $0.55 \pm 0.13$ \\
\hline Methane content & $\%$ & $56.25 \pm 1.93$ & $56.56 \pm 1.58$ & $56.16 \pm 2.06$ & $55.22 \pm 1.98$ & $55.57 \pm 2.50$ \\
\hline
\end{tabular}

\subsection{Kinetics}

In the quasi-flow system, the reactor was fed once a day with the portion of substrate or substrates and the same volume of digested medium was removed from the reactor. For this reason, the production of biogas between each feeding related to a temporal interval of $0-24 \mathrm{~h}$. Accordingly, 
the reaction rate constant was expressed in hours, distinct from the typical units used for batch experiments $\left(\mathrm{d}^{-1}\right)$. The average volume of biogas produced day by day (calculated for the exemplary 30 measurement days) is shown in Figure 4.

a)

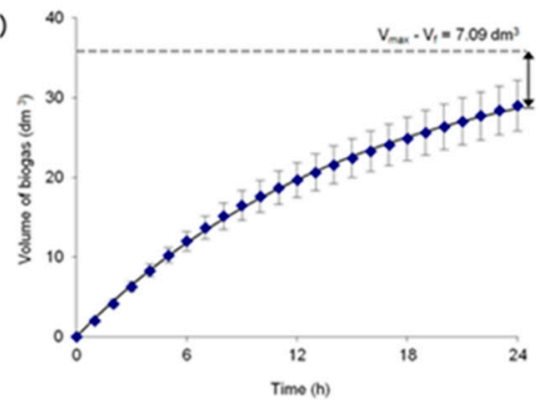

b)

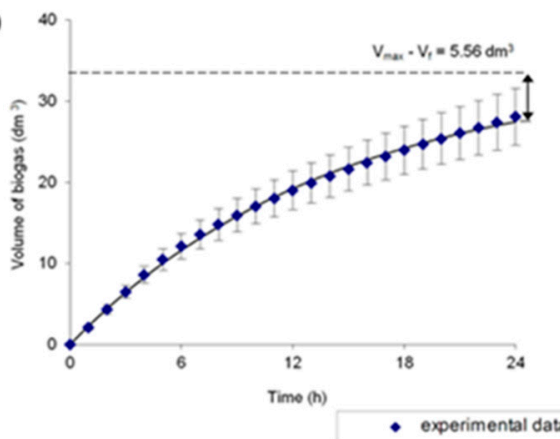

c)

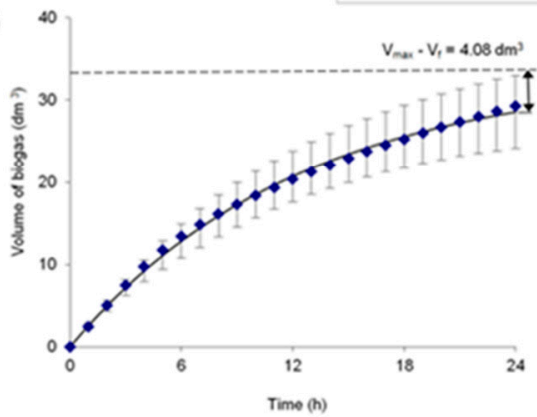

d)

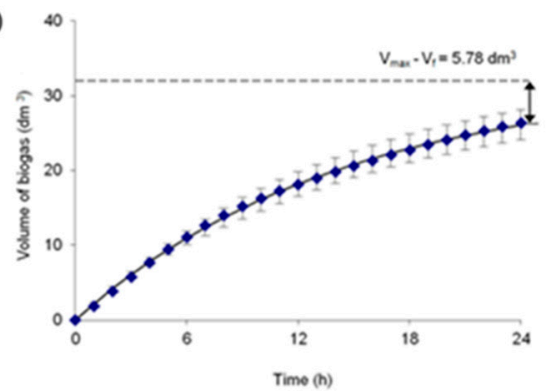

e)

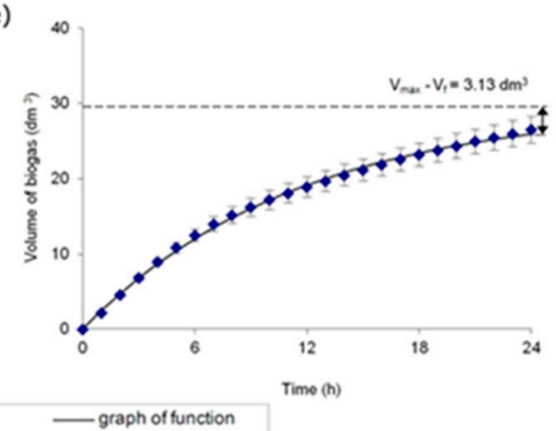

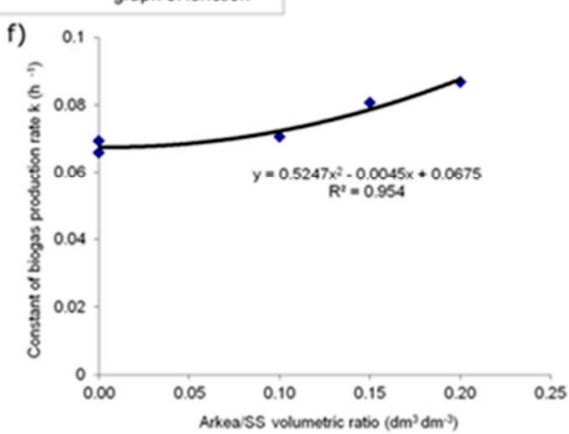

\begin{tabular}{lccccc}
\hline \multicolumn{1}{c}{ Parameter } & $\mathrm{R} 1$ & $\mathrm{R} 2$ & $\mathrm{R} 3$ & $\mathrm{R} 4$ & $\mathrm{R} 5$ \\
\hline Constant of biogas production rate $\mathrm{k}\left(\mathrm{h}^{-1}\right)$ & 0.066 & 0.071 & 0.081 & 0.069 & 0.087 \\
Maximum biogas production $\mathrm{V}_{\max }\left(\mathrm{dm}^{3}\right)$ & 36.12 & 33.64 & 33.42 & 32.15 & 29.63 \\
\hline Coefficient of determination $\mathrm{R}^{2}$ & 0.9993 & 0.9986 & 0.9978 & 0.9993 & 0.9985 \\
\hline
\end{tabular}

Figure 4. Biogas production in time (the average values from 30 measurement days and standard deviations are given), the values of kinetic constants and coefficients of determination for specified reactors: (a) R1, (b) R2, (c) R3, (d) R4, (e) R5, and (f) k constant as a function of Arkea/SS volumetric ratio.

For a mathematical description of the changes in the biogas volume $(\mathrm{V})$ produced in time $(\mathrm{t})$, the most appropriate was the equation of first-order reaction [33] as $V=V_{\max }(1-\exp (-\mathrm{k} \cdot \mathrm{t}))$. This was confirmed by the determination coefficients $\left(R^{2}\right)$. The experimental data allowed to determine the reaction rate constant $(\mathrm{k})$ and the maximum gas volume $\left(\mathrm{V}_{\max }\right)$, which theoretically can be derived from the feed portion feeding the reactor once a day.

The results indicate that the biogas production rate constants for sewage sludge were comparable and equaled $0.066 \mathrm{~h}^{-1}$ and $0.069 \mathrm{~h}^{-1}$ for R1 and R4, respectively. In the bioaugumented reactors, the $\mathrm{k}$ values were $0.071 \mathrm{~h}^{-1}, 0.081 \mathrm{~h}^{-1}$, and $0.087 \mathrm{~h}^{-1}$ in R2, R3, and R5, respectively. It was probably caused 
by the enhanced microorganisms' activity in the bioaugmented systems. This was confirmed by the increased biogas production rate constant $\mathrm{k}$. The $\mathrm{k}$ value increased with the increasing the dose of bioaugmenting mixture, according to the equation $y=0.5247 x^{2}-0.0045 x+0.0675$ (Figure 4f).

In each phase, the differences between the maximum biogas production from the reactor feed $\left(\mathrm{V}_{\max }\right)$ and the actual value of biogas production obtained after the period of $24 \mathrm{~h}\left(\mathrm{~V}_{\mathrm{f}}\right)$ were determined (Figure 4). The difference $V_{\max }-V_{f}$ corresponds to the value of biogas potential in the digest and varied from 3.13 to $7.09 \mathrm{dm}^{3}$ in the reactors. The best results were obtained in the bioaugmented reactors, with increasing doses of bioaugmenting mixture in the feedstock. In such cases, the untapped biogas potential decreased and amounted to $16.5 \%$ (R2), $12.0 \%$ (R3), and $10.6 \%$ (R5). In the control runs, the untapped biogas potential was higher and was up to $19.6 \%$ and $17.8 \%$ (R1 and $\mathrm{R} 4$, respectively). Bioaugmentation of digested sewage sludge resulted in an enhancement of the metabolism transformation rate, which was associated with the increase of process efficiency.

Importantly, the influence of the feed changes on the kinetics results determined on the basis of continuous data acquisition throughout experiment time was shown. This was revealed in terms of standard deviation growing within $24 \mathrm{~h}$ for the analyzed 30 measurement days.

\subsection{Changes in Digest Morphology}

The scanning electron microscopy was used to observe the microbial aggregates in the digest structure, the space relationship between microorganisms, as well as the presence of extracellular polymeric substances (EPS) and other materials.

While analyzing the structure of the digested sludge, it was noted that despite the shortened HRT, larger agglomerates of microorganisms were formed in the bioaugmented reactors compared to the non-bioaugmented sludge (Figure 5). This was beneficial for the subsequent digest dewatering because of the extended sludge sediments capability (unpublished data). On the basis of the operation strategy ensuring comparable OLR value for both the bioaugmented and non-bioaugmented reactors, the observed effect could be largely attributed to extended EPS secretion by microorganisms [34,35] through bioaugmentation, and thus lower shear sensitivity and lower degree of dispersion [36]. According to the study of $\mathrm{Yu}$ et al. [37], the microbial community composition and its activity affected both the EPS production and composition. Interestingly, in the structure of the bioaugmented digest, the changes in the morphology of EPS were clearly visible. EPS began to collapse and condense into fiber-like structures [38]. Similarly, the differences referring to methanogens seem to indicate a response in their cell shapes to bioaugmentation that was reported by Zhang et al. [39].

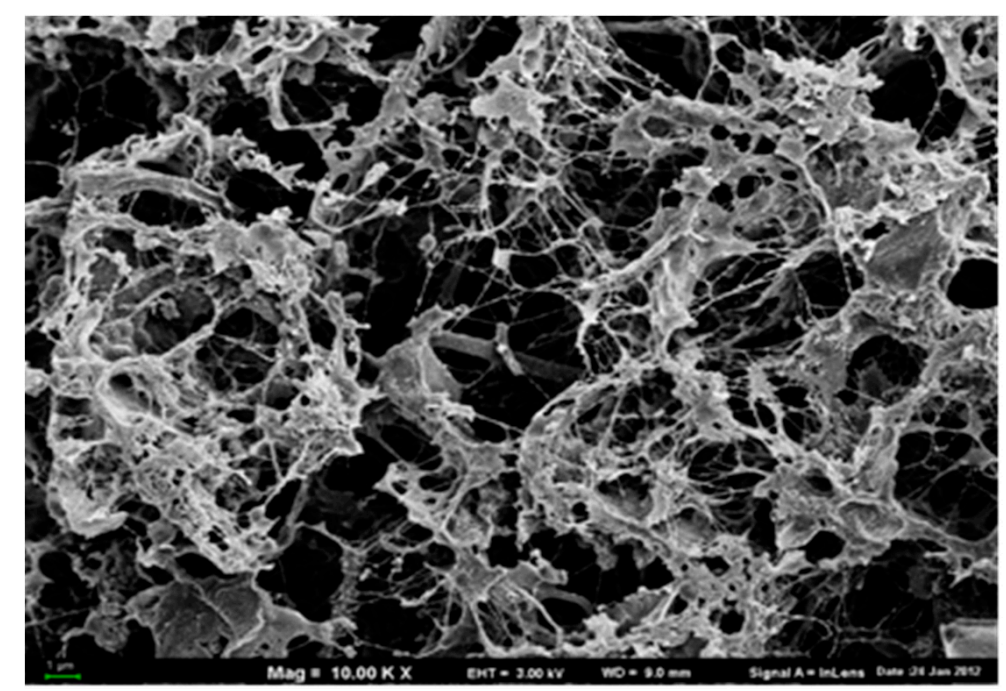

(a)

Figure 5. Cont. 


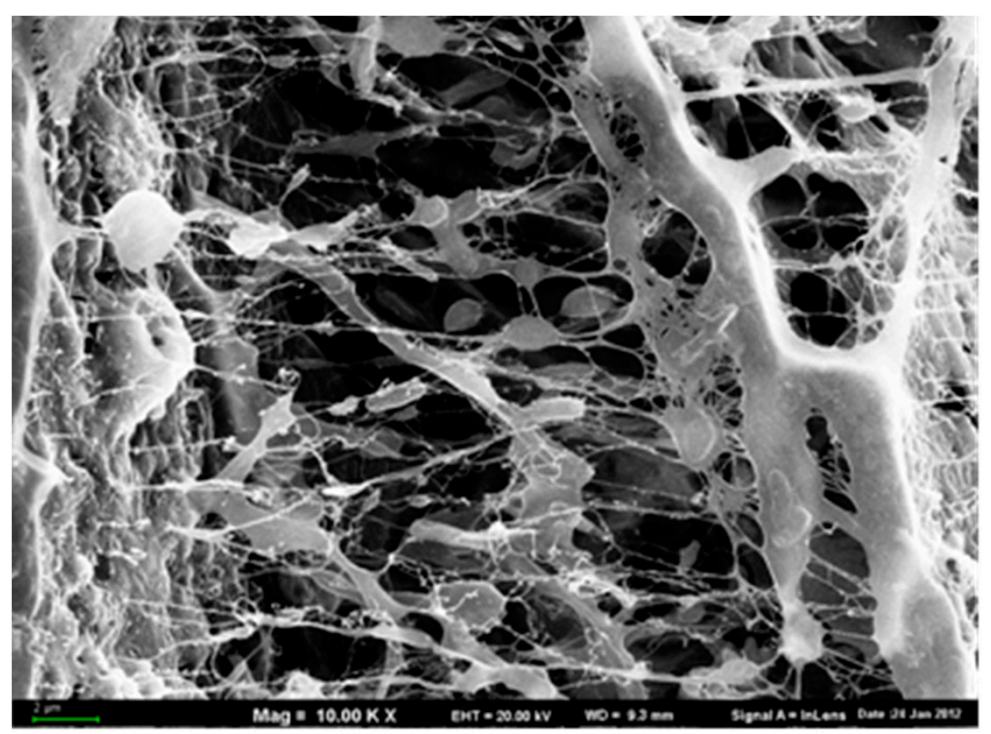

(b)

Figure 5. SEM micrograph of non-bioaugmented (a) and bioaugmented (b) digested sewage sludge (magnification $10 \times$ ).

\subsection{Microbial Structure of Digesters}

Sludge fermentation starts with hydrolysis followed by acidogenesis. In both these processes, the predominant microorganisms are obligatory anaerobes and facultative bacteria. Microorganisms conducting acetogenesis produce hydrogen and are in symbiosis with methanogenic archaea, which consume hydrogen (syntrophy or interspecies hydrogen transfer-IHT). The balance between methanogens and microorganisms involved in acido- and acetogenesis is crucial because if the activity of the latter is too high, anaerobic digestion will fail due to the acidification of the reactor.

The microbial structure of the biomass from the reactors operated in the first phase of the experiment was analyzed using next-generation sequencing. Rarefaction analysis was used to characterize the richness of taxa in the experimental digesters. At the genus level, the curves leveled off, indicating acceptable sampling and coverage of the richness in the samples (data not shown). The microbial diversity of the biomass was the highest in the control reactor $\left(\mathrm{H}^{\prime}=2.86\right)$ and decreased gradually to $\mathrm{H}^{\prime}=2.52$ and $\mathrm{H}^{\prime}=2.16$ in $\mathrm{R} 2$ and $\mathrm{R} 3$, respectively, as the dose of bioaugmenting mixture was increased. In the reactors, Bacteria predominated and Archaea constituted between $1.3 \%$ and $1.4 \%$ of identified sequences (Table 3).

Table 3. Percentage of bacterial taxa in biomass from the experimental reactors.

\begin{tabular}{llll}
\hline \multicolumn{1}{c}{ Kingdom; Phylum; Class; Order; Family; Genus } & R1 & R2 & R3 \\
\hline Bacteria; Verrucomicrobia; Verrucomicrobiae; Verrucomicrobiales; Unclassified & 3.1 & 1.0 & 0.4 \\
\hline Bacteria; Unclassified & 31.0 & 38.8 & 52.7 \\
\hline Bacteria; Thermotogae; Thermotogae; Thermotogales; Unclassified & 4.4 & 2.8 & 4.2 \\
\hline Bacteria; Synergistetes; Synergistia; Synergistales; Synergistaceae; Synergistes & 0.5 & 0.3 & 0.1 \\
\hline Bacteria; Spirochaetes; Unclassified & 2.8 & 3.9 & 3.9 \\
\hline Bacteria; Spirochaetes; Spirochaetia; Unclassified & 0.8 & 0.3 & 0.3 \\
\hline Bacteria; Proteobacteria; Unclassified & 0.4 & 0.5 & 0.3 \\
\hline Bacteria; Proteobacteria; Gammaproteobacteria; Xanthomonadales; Xanthomonadaceae; Thermomonas & 0.5 & 0.4 & 0.3 \\
\hline
\end{tabular}


Table 3. Cont.

\begin{tabular}{llll}
\hline \multicolumn{1}{c}{ Kingdom; Phylum; Class; Order; Family; Genus } & R1 & R2 & R3 \\
\hline Bacteria; Proteobacteria; Gammaproteobacteria; Pseudomonadales; Pseudomonadaceae; Pseudomonas & 0.8 & 3.9 & 3.6 \\
\hline Bacteria; Proteobacteria; Deltaproteobacteria; Syntrophobacterales; Unclassified; Unclassified & 0.8 & 1.2 & 0.8 \\
\hline Bacteria; Proteobacteria; Deltaproteobacteria; Syntrophobacterales; Syntrophaceae; Syntrophus & 1.4 & 1.8 & 1.7 \\
\hline Bacteria; Proteobacteria; Deltaproteobacteria; Syntrophobacterales; Syntrophaceae; Smithella & 0.9 & 0.8 & 0.7 \\
\hline Bacteria; Proteobacteria; Deltaproteobacteria; Desulfobacterales; Desulfobacteraceae; Desulfofaba & 0.7 & 1.3 & 1.0 \\
\hline Bacteria; Proteobacteria; Betaproteobacteria; Rhodocyclales; Rhodocyclaceae; Dechloromonas & 0.5 & 0.4 & 0.3 \\
\hline Bacteria; Proteobacteria; Betaproteobacteria; Burkholderiales; Comamonadaceae; Rhodoferax & 1.3 & 1.0 & 0.7 \\
\hline Bacteria; Proteobacteria; Betaproteobacteria; Burkholderiales; Comamonadaceae; Diaphorobacter & 0.8 & 0.8 & 0.5 \\
\hline Bacteria; Proteobacteria; Betaproteobacteria; Burkholderiales; Comamonadaceae; Acidovorax & 0.5 & 0.4 & 0.4 \\
\hline Bacteria; Firmicutes; Unclassified & 0.8 & 0.7 & 0.3 \\
\hline Bacteria; Firmicutes; Clostridia; Clostridiales; Clostridiaceae; Clostridium & 0.5 & 0.5 & 0.3 \\
\hline Bacteria; Cloacimonetes; Unclassified & 7.1 & 6.5 & 3.6 \\
\hline Bacteria; Chloroflexi; Unclassified & 1.2 & 0.7 & 0.5 \\
\hline Bacteria; Chloroflexi; Anaerolineae; Anaerolineales; Unclassified & 1.4 & 0.8 & 0.4 \\
\hline Bacteria; Bacteroidetes; Sphingobacteriia; Sphingobacteriales; Unclassified; Unclassified & 0.7 & 0.4 & 0.3 \\
\hline Bacteria; Bacteroidetes; Cytophagia; Cytophagales; Cytophagaceae; Cytophaga & 18.9 & 16.8 & 12.3 \\
\hline Bacteria; Bacteroidetes; Bacteroidia; Bacteroidales; Bacteroidaceae; Bacteroides & 1.9 & 0.7 & 0.6 \\
\hline Bacteria; Actinobacteria; Actinobacteria; Micrococcales; Intrasporangiaceae; Tetrasphaera & 0.5 & 0.4 & 0.4 \\
\hline Bacteria; Actinobacteria; Actinobacteria; Micrococcales; Dermatophilaceae; Dermatophilus & 1.1 & 0.8 & 0.7 \\
\hline Archaea; Unclassified & 0.5 & 0.4 & 0.3 \\
\hline Archaea; Euryarchaeota; Methanomicrobia; Methanomicrobiales; Methanomicrobiaceae; Methanoculleus & 0.8 & 1.0 & 1.0 \\
\hline Low abundance * & 9.2 & 7.5 & 5.4 \\
\hline No Hit & 4.5 & 3.5 & 2.1 \\
\hline
\end{tabular}

* In the table only bacterial taxa with abundance over $0.5 \%$ were presented.

This value was one order of magnitude lower than for example the one noted in mesophilic full-scale digesters with sewage sludge [24]; however, it was similar to the values noted in mesophilic reactors for co-digesting of fish waste and cow manure (about 1\%) [7] or solid-state digesters fed with kitchen waste, pig manure and excess sludge (about 0.5\%) [40]. In this study, despite being only a small fraction of the entire microbial community, Archaea ensured efficient production of methane-rich biogas.

The structure of the biomass in the reactors differed from that of the mixture for bioaugmentation. This indicates that most of the microbes in the mixture were not able to survive in the reactors; however, the ones that survived improved the efficiency of methane fermentation as concluded based on the rate constant for biogas production and efficiency of SCOD removal. Within the biomass, the percentage of unclassified bacteria increased with increasing dose of bioaugmenting mixture showing that high diversity of yet unknown microorganisms was present in the reactor as a result of bioaugmentation.

Among Bacteria, the core communities belonged to the phyla Thermotogae, Spirochaetes, Cloacimonetes, Actinobacteria, Bacteroidetes, Chloroflexi, Firmicutes, and Proteobacteria. Bacteroidetes, Chloroflexi, Firmicutes, and Proteobacteria contain most of the identified species of acidogenic bacteria that support the hydrolysis stage [41]. Microorganisms belonging to class Cytophagia predominated in the biomass (12.3-18.9\%). However, as doses of the bioaugmenting mixture were increased, the percentage of Cytophaga sp. decreased; this was a strong association, with an $R^{2}$ value of 0.91 , indicating that $91 \%$ of the variation in Cytophaga sp. abundance was associated with the dose of bioaugmenting mixture. Similarly, an increased dose of this mixture was associated with decreases in the percent abundance of the order Verrucomicrobiales $\left(R^{2}=1.00\right)$, the phyla Cloacimonetes $\left(R^{2}=0.83\right)$, and Choroflexi $\left(R^{2}=1.00\right)$, including order Anaerolineales $\left(R^{2}=0.99\right)$. 
Members of the genus Cytophaga are important for anaerobic decomposition of biopolymers, such as xylan or cellulose. Cytophaga xylanolytica is a mesophilic anaerobe that grows by fermentation of mono-, $\mathrm{di}-$, and polysaccharides (but not cellulose) to acetate, propionate, succinate, $\mathrm{CO}_{2}$, and $\mathrm{H}_{2}$; xylan-grown cells of this species have xylanase and various glycosidase activities. Cytophaga hutchinsonii can rapidly digest crystalline cellulose without free cellulases or cellulosomes [42]. As extracellular polymeric substances may comprise up to $30 \%$ of activated sludge, these activities of Cytophaga sp. may be crucial for efficient degradation of organics in fermented sludge.

The abundance of Pseudomonas sp. increased from $0.4 \%$ in R1 to nearly $4 \%$ in bioaugmented $\mathrm{R} 2$ and R3 and it was the only identified genus whose abundance increased by such a large amount. Such an increase can be advantageous for anaerobic digestion because Duran et al. [31] observed that the presence of selected strains of genera Pseudomonas, Bacillus, and Actinomycetes improved the anaerobic digestion of biosolids, increasing net $\mathrm{CH}_{4}$ production by $29 \%$ and diminished odor formation. In addition, Xia et al. [43] reported that an increase in the proportion of some functional organisms, including Pseudomonas sp., led to an increase in the efficiency of anaerobic digestion when the proportion of more biodegradable, low molecular weight fractions $(<20 \mathrm{kDa})$ was increased 10 times because of solubilization of some of the proteins, polysaccharides, nucleic acids, and humic-like substances. In our study, the concentration of low molecular weight SCOD in the digest was negatively correlated $\left(\mathrm{R}^{2}=0.97\right)$ with the abundance of Pseudomonas sp. in the biomass in the bioaugmented reactors, indicating that this genus played an important role in SCOD degradation.

Syntrophic bacteria comprised a significant part of the biomass. From 3.6 to $7.1 \%$ of the identified sequences belonged to syntrophic prokaryotes from phylum Cloacimonetes. The analysis of the proteome of Candidatus Cloacimonas acidaminovorans indicated that this bacterium derives carbon and energy from the fermentation of amino acids and that it is a syntroph producing $\mathrm{H}_{2}$ and $\mathrm{CO}_{2}$ from formate [44]. On the other hand, the abundance of phylum Cloacimonetes was linked with lowered methane production in reactors fed with protein-rich substrates [7]. In this study, the abundance of other syntrophic microorganisms belonging to Syntrophus sp. and Smithella sp. was relatively stable in the reactors (1.4-1.8\% and $0.7-0.9 \%$, respectively). Smithella sp. are syntrophic acetogens involved in propionate degradation in anaerobic digesters, while Syntrophus sp. oxidates fatty acids and benzoate [41,45].

During the methane fermentation, Methanomicrobiales are usually less numerous than Methanosarcinales [8]. In this study, the predominance of Methanomicrobiales (about $1 \%$ of all identified sequences) in the species structure of Archaea indicated hydrogenotrophic methanogenesis as the main pathway of methane generation. Although Methanosaeta sp. predominated in the liquor used for bioaugmentation, Methanoculleus was the most abundant genus in the reactors. The idea of the study was to bioaugment the reactor with Archaea microorganisms to support methane production because this is the most critical step in the anaerobic digestion conducted by slow-growing microorganisms and prone to changes in environmental conditions. From the microbial analysis of biomass, it can be concluded that the biodiversity of bioaugmenting mixture reflecting the potential of different species to colonize the fermentation reactors was low (only 11 species with abundance over $0.5 \%$ ). Despite this, bioaugmentation was successful in terms of the most abundant group that is Methanosaeta sp. belonging to Methanosarcinales that produce methane via an acetotrophic pathway. This genus was present in the experimental reactors, but its abundance was below $0.5 \%$. Methanosaeta $\mathrm{sp}$. is sensitive to OLR. They were abundant in the mesophilic fermentation reactors that were operated at an OLR of $1 \mathrm{~kg} \mathrm{COD} \mathrm{m}^{-3}$ day $^{-1}$ but the increase in OLR to $2 \mathrm{~kg} \mathrm{COD} \mathrm{m}^{-3}$ day $^{-1}$, at the maintained process temperature, caused their disappearance from the biomass [46]. In the present study, OLR was higher than the optimal for Methanosaeta sp.; therefore, although present in the biomass, they were not able to outcompete Methanoculleus sp. that predominated in the reactors. Methanoculleus sp. commonly occurs in digesters operated in meso- and thermophilic temperatures, including the digesters in which the process is supported by physico-chemical treatment, e.g., microwave radiation [46]. Methanoculleus sp. cope well with high OLRs, comprising over $40 \%$ of biomass during thermophilic co-digestion 
of manure and waste whey at an OLR of $60.4 \mathrm{~g} \mathrm{COD} \mathrm{m}^{-3}$ day $^{-1}$ [40]. This fact may explain the predominance in the present study of this genera among Archaea in the experimental reactors operated at the higher OLRs.

\section{Conclusions}

Bioaugmentation decreased the HRT from $20 \mathrm{~d}$ to $16.7 \mathrm{~d}$, but despite this decrease, the observed daily biogas production, methane content in the biogas and the biogas yield per kg of VS were similar in bioaugmented and control reactors. With bioaugmentation, SCOD removal improved, especially in reactors operated at higher OLR, which can be attributed to the increase in the rate of biogas production. Regardless of loading, the value of $\mathrm{k}$ was higher in bioaugmented reactors than in control reactors. The structure of the biomass in all reactors was different from that of the mixture for bioaugmentation and bioaugmentation diminished species diversity. In all digesters, bacteria belonging to Thermotogae, Spirochaetes, Cloacimonetes, Bacteroidetes, and Proteobacteria predominated with cellulose-hydrolyzing Cytophaga as the most abundant genus. The abundance of Pseudomonas sp. increased as the dose of bioaugmentative mixture was increased. The predominance of Methanoculleus sp. among Archaea indicated that hydrogenotrophic methanogenesis was the main pathway of methane generation.

Author Contributions: Conceptualization, A.M. and M.L.; Methodology, A.M., M.L. and A.C.-K.; Software, M.L., A.M. and A.C.-K.; Validation, M.L., A.M. and A.C.-K.; Formal Analysis, M.L., A.M. and A.C.-K.; Investigation, A.M., M.L. and A.C.-K.; Resources, A.M., M.L. and A.C.-K.; Data Curation, A.M., M.L. and A.C.-K.; Writing-Original Draft Preparation, M.L., and A.C.-K.; Writing-Review \& Editing, A.M., M.L. and A.C.-K.; Visualization, A.M., M.L. and A.C.-K.; Supervision, A.M.; Project Administration, A.M. and A.C.-K.; Funding Acqusition, A.M. and A.C.-K.

Funding: The authors thank for the financial aid from the National Centre of Science (Poland), No.7405/B/T02/2011/40 and financial aid from the Ministry of Science and Higher Education in Poland (Statutory Research, 18.610.006-300).

Conflicts of Interest: The authors declare no conflict of interest.

\section{References}

1. Maj Duong, T.H.; Smits, M.; Vestraete, W.; Carballa, M. Enhanced biomethanation of kitchen waste by different pretreatments. Bioresour. Technol. 2011, 102, 592-599. [CrossRef]

2. Satoh, H.; Okabe, S.; Yamaguchi, Y.; Watanabe, Y. Evaluation of the impact of bioaugmentation and biostimulation by in situ hybridization and microelectrode. Water Res. 2003, 37, 2206-2216. [CrossRef]

3. Timmis, K.N. Handbook of Hydrocarbon and Lipid Microbiology; Springer: Berlin, Germany, 2010; ISBN 978-3-54-077584-3.

4. Cycoń, M.; Mrozik, A.; Piotrowska-Seget, Z. Bioaugmentation as a strategy for remediation of pesticide-polluted soil: A review. Chemosphere 2017, 172, 52-71. [CrossRef] [PubMed]

5. Chen, Q.; Ni, J.; Ma, T.; Liu, T.; Zheng, M. Bioaugmentation treatment of municipal wastewater with heterotrophic-aerobic nitrogen removal bacteria in a pilot-scale SBR. Bioresour. Technol. 2015, 183, $25-32$. [CrossRef] [PubMed]

6. Neumann, L.; Scherer, P. Impact of bioaugmentation by compost on the performance and ecology of an anaerobic digester fed with energy crops. Bioresour. Technol. 2007, 102, 2931-2935. [CrossRef] [PubMed]

7. Solli, L.; Håvelsrud, O.E.; Horn, S.J.; Rike, A.G. A metagenomic study of the microbial communities in four parallel biogas reactors. Biotechnol. Biofuels 2014, 7, 146. [CrossRef] [PubMed]

8. Tabatabaei, M.; Rahim, R.A.; Abdullah, N.; Wright, A.-D.G.; Shirai, Y.; Sakai, K.; Sulaiman, A.; Hassan, M.-A. Importance of the methanogenic archaea populations in anaerobic wastewater treatments. Process Biochem. 2010, 45, 1214-1225. [CrossRef]

9. Nielsen, H.B.; Mladenovska, Z.; Ahring, B.K. Bioaugmentation of a two-stage thermophilic $\left(68^{\circ} \mathrm{C} / 55^{\circ} \mathrm{C}\right)$ anaerobic digestion concept for improvement of the methane yield from cattle manure. Biotechnol. Bioeng. 2007, 97, 1638-1643. [CrossRef] [PubMed] 
10. Li, P.; Wang, Y.; Wang, Y.; Jiang, Z.; Tong, L. Bioaugmentation of cellulose degradation in swine wastewater treatment with a composite microbial consortium. Fresen. Environ. Bull. 2010, 19, 3107-3112. [CrossRef]

11. Wang, A.; Ren, N.; Shi, Y.; Lee, D.-J. Bioaugmented hydrogen production from microcrystalline cellulose using co-culture-Clostridium acetobutylicum $\mathrm{X}_{9}$ and Ethanoigenensharbinense $\mathrm{B}_{49}$. Int. J. Hydrogen Energy 2008, 33, 912-917. [CrossRef]

12. Cirne, D.G.; Bjornssom, L.; Alves, M.; Mattiasson, B. Effects of bioaugmentation by an anaerobic lipolytic bacterium on anaerobic digestion of lipid-rich waste. J. Chem. Technol. Biotechnol. 2006, 81, 1745-1752. [CrossRef]

13. Venkiteshwaran, K.; Milferstedt, K.; Hamelin, J.; Zitomer, D.H. Anaerobic digester bioaugmentation influences quasi steady state performance and microbial community. Water Res. 2016, 104, 128-136. [CrossRef] [PubMed]

14. Schmidt, J.E.; Larsen, S.B.; Karakashev, D. Ex-situ bioremediation of polycyclic aromatic hydrocarbons in sewage sludge. WIT Trans. Ecol. Environ. 2008, 10, 189-198. [CrossRef]

15. Poszytek, K.; Pyzik, A.; Sobczak, A.; Lipinski, L.; Sklodowska, A.; Drewniak, L. The effect of the source of microorganisms on adaptation of hydrolytic consortia dedicated to anaerobic digestion of maize silage. Anaerobe 2017, 46, 46-55. [CrossRef] [PubMed]

16. Li, Y.; Zhang, Y.; Sun, Y.; Wu, S.; Kong, X.; Yuan, Z.; Dong, R. The performance efficiency of bioaugmentation to prevent anaerobic digestion failure from ammonia and propionate inhibition. Bioresour. Technol. 2017, 231, 94-100. [CrossRef] [PubMed]

17. Schauer-Gimenez, A.E.; Zitomer, D.H.; Maki, J.H.; Struble, C.A. Bioaugmentation for improved recovery of anaerobic digesters after toxicant exposure. Water Res. 2010, 44, 3555-3564. [CrossRef] [PubMed]

18. Tale, V.P.; Maki, J.S.; Zitomer, D.H. Bioaugmentation of overloaded anaerobic digesters restores function and archaeal community. Water Res. 2015, 70, 138-147. [CrossRef] [PubMed]

19. Herrero, M.; Stuckey, D.C. Bioaugmentation and its application in wastewater treatment: A review. Chemosphere 2015, 140, 119-128. [CrossRef] [PubMed]

20. Mehariya, S.; Patel, A.K.; Obulisamy, P.K.; Punniyakotti, E.; Wong, J.W.C. Co-digestion of food waste and sewage sludge for methane production: Current status and perspective. Bioresour. Technol. 2018. [CrossRef] [PubMed]

21. Raper, E.; Stephenson, T.; Anderson, D.R.; Fisher, R.; Soares, A. Industrial wastewater treatment through bioaugmentation. Process Saf. Environ. Prot. 2018, 118, 178-187. [CrossRef]

22. Zhang, Q.-Q.; Yang, G.-F.; Zhang, L.; Zhang, Z.-Z.; Tia, G.-M.; Jin, R.-C. Bioaugmentation as a useful strategy for performance enhancement in biological wastewater treatment undergoing different stresses: Application and Mechanisms. Crit. Rev. Environ. Sci. Technol. 2017, 47, 1877-1899. [CrossRef]

23. American Public Health Association. Standard Methods for the Examination of Water \& Wastewater, Centennial Edition 21 ed.; American Public Health Association: Washington, DC, USA, 2005.

24. Świątczak, P.; Cydzik-Kwiatkowska, A.; Rusanowska, A. Microbiota of anaerobic digesters in full-scale wastewater treatment plant. Arch. Environ. Prot. 2017, 43, 53-60. [CrossRef]

25. Edgar, R.C.; Haas, B.J.; Clemente, J.C.; Quince, C.; Knight, R. UCHIIME improves sensitivity and speed of chimera detection. Bioinformatics 2011, 27, 2194-2200. [CrossRef] [PubMed]

26. Edgar, R.C. Search and clustering orders of magnitude faster than BLAST. Bioinformatics 2010, 26, $2460-2461$. [CrossRef] [PubMed]

27. Nawrocki, E.P.; Eddy, S.R. Infernal 1. 1, 100-fold faster RNA homology searches. Bioinformatics 2013, 29, $2933-2935$. [CrossRef] [PubMed]

28. Hill, T.C.J.; Walsh, K.A.; Harris, J.A.; Moffett, B.A. Using ecological diversity measures with bacterial communities. FEMS Microbiol. Ecol. 2003, 43, 1-11. [CrossRef] [PubMed]

29. Yu, D.; Yang, Y.; Teng, F.; Feng, L.; Fang, X.; Ren, H. Bioaugmentation treatment of mature landfill leachate by new isolated ammonia nitrogen and humic acid resistant microorganisms. J. Microbiol. Biotechnol. 2014, 24, 987-997. [CrossRef] [PubMed]

30. Hailei, W.; Guosheng, L.; Ping, L.; Feng, P. The effect of bioaugmentation on the performance of sequencing batch reactor and sludge characteristics in the treatment process of papermaking wastewater. Bioprocess Biosyst. Eng. 2006, 29, 283-289. [CrossRef] [PubMed] 
31. Duran, M.; Tepe, N.; Yurtsever, D.; Punzi, V.L.; Bruno, C.; Mehta, R.J. Bioaugmenting anaerobic digestion of biosolids with selected strains of Bacillus, Pseudomonas, and Actinomycetes species for increased methanogenesis and odor control. Appl. Microbiol. Biotechnol. 2006, 73, 960-966. [CrossRef] [PubMed]

32. Poszytek, K.; Karczewska-Golec, J.; Jakusz, G.; Krucon, T.; Lomza, P.; Zhenfdong, Y.; Drewniak, L.; Ciok, A.; Decewicz, P.; Dziurzynski, M.; et al. Genome-Guided characterization of Ochrobactrum sp. POC9 enhancing sewage sludge utilization-Biotechnological potential and biosafety consideration. Int. J. Environ. Res. Public Health 2018, 15, 1501. [CrossRef] [PubMed]

33. Gavala, N.H.; Angelidaki, I.; Ahring, B.K. Kinetics and modeling of anaerobic digestion process. Adv. Biochem. Eng. Biotechnol. 2002, 81, 57-93.

34. Sheng, G.-P.; Yu, H.-Q.; Li, X.-Y. Extracellular polymeric substances (EPS) of microbial aggregates in biological wastewater treatment systems: A review. Biotechnol. Adv. 2010, 28, 882-894. [CrossRef] [PubMed]

35. Yang, Z.H.; Xu, R.; Zheng, Y.; Chen, T.; Zhao, L.-J.; Li, M. Characterization of extracellular polymeric substances and microbial diversity in anaerobic co-digestion reactor treated sewage sludge with fat, oil, grease. Bioresour. Technol. 2016, 212, 164-173. [CrossRef] [PubMed]

36. Mikkelsen, L.H.; Keiding, K. Physico-chemical characteristics of full scale sewage sludges with implication to dewatering. Water Res. 2002, 36, 2451-2462. [CrossRef]

37. Yu, Z.; Wen, X.; Xu, M.; Huang, X. Characteristics of extracellular polymeric substances and bacterial communities in an anaerobic membrane bioreactor coupled with online ultrasound equipment. Bioresour. Technol. 2012, 117, 333-340. [CrossRef] [PubMed]

38. Dohnalkova, A.C.; Marshall, M.J.; Arey, B.W.; Williams, K.H.; Bukc, E.C.; Fredrickson, J.K. Imaging hydrated microbial extracellular polymers: Comparative analysis by electron microscopy. Appl. Environ. Microbiol. 2017, 77, 1254-1262. [CrossRef] [PubMed]

39. Zhang, J.; Dong, H.; Zhao, L.; McCarrick, R.; Agrawal, A. Microbial reduction and precipitation of vanadium by mesophilic and thermophilic methanogens. Chem. Geol. 2014, 370, 29-39. [CrossRef]

40. Li, A.; Chu, Y.; Wang, X.; Ren, R.; Yu, J.; Liu, X.; Yan, J.; Zhang, L.; Wu, S.; Li, S. A pyrosequencing-based metagenomic study of methane-producing microbial community in solid-state biogas reactor. Biotechnol. Biofuels 2013, 6, 3. [CrossRef] [PubMed]

41. Venkiteshwaran, K.; Bocher, B.; Maki, J.; Zitomer, D.H. Relating Anaerobic Digestion Microbial Community and Process Function. Microbiol. Insights 2015, 8, 37-44. [CrossRef] [PubMed]

42. Haack, S.H.; Breznak, J.A. Cytophaga xylanolytica sp. nov., a xylan-degrading, anaerobic gliding bacterium. Arch. Microbiol. 1993, 159, 6-15. [CrossRef]

43. Xia, S.; Zhou, Y.; Eustance, E.; Zhang, Z. Enhancement mechanisms of short-time aerobic digestion for waste activated sludge in the presence of cocoamidopropyl betaine. Sci. Rep. 2017, 7, 13491. [CrossRef] [PubMed]

44. Pelletier, E.; Kreymeyer, A.; Bocs, S.; Rouy, Z.; Gyapay, G.; Chouari, R.; Riviere, D.; Ganesan, P.; Daegelen, A.; Sghir, A.; et al. "Candidatus Cloacamonas acidaminovorans": Genome sequence reconstruction provides a first glimpse of a new bacterial division. J. Bacteriol. 2008, 190, 2572-2579. [CrossRef] [PubMed]

45. Jackson, B.E.; Bhupathiraju, V.K.; Tanner, R.S.; Woese, C.R.; McInerney, M.J. Syntrophus aciditrophicus sp. nov., a new anaerobic bacterium that degrades fatty acids and benzoate in syntrophic association with hydrogen-using microorganisms. Arch. Microbiol. 1999, 171, 107-114. [CrossRef] [PubMed]

46. Zielińska, M.; Cydzik-Kwiatkowska, A.; Zieliński, M.; Dębowski, M. Impact of temperature, microwave radiation and organic loading rate on methanogenic community and biogas production during fermentation of dairy wastewater. Bioresour. Technol. 2013, 129, 308-314. [CrossRef] [PubMed]

(C) 2018 by the authors. Licensee MDPI, Basel, Switzerland. This article is an open access article distributed under the terms and conditions of the Creative Commons Attribution (CC BY) license (http://creativecommons.org/licenses/by/4.0/). 